УДК 930.2:373(091)(477.8)“1944/1953”

DOI:

Марія Ярушак, кандидат педагогічних наук, доцент кафедри загальної педагогіки та дошкільної освіти Дрогобииького державного педагогічного університету імені Івана Франка

Олександра Свйонтик, кандидат педагогічних наук, дочент кафедри загальної педагогіки та дошкільної освіти Дрогобицького державного педагогічного університету імені Івана Франка Микола Галів, доктор педагогічних наук, доцент кафедри історії України Дрогобицького державного педагогічного університету імені Івана Франка

\title{
ЗАГАЛЬНООСВІТНЕ ШКІЛЬНИЦТВО ЗАХІДНИХ ОБЛАСТЕЙ УКРАЇНИ (1944 - 1953) У ВИМІРАХ ІСТОРІЇ ПОВСЯКДЕННЯ (історіографічний аспект)
}

У статті проаналізовано сучасну украӥнську історіографію повсякденних аспектів загальноосвітнього шкільництва західних областей України периих повоєнних років (1944-1953). Встановлено, шуо сучасна українська історіографія повсякденного життя загальноосвітніх шкіл західних областей Украӥни периих післявоєнних років налічує декілька десятків наукових праџьь. Автори запропонували поділ иүих праџь на три групи: 1) праці з історії икільництва західних областей України у 1944-1953 рр.; 2) студії з історії повсякденного життя різних сочіальних середовищ, до яких належали школярі на західноукраӥнських землях окресленого періоду; 3) дослідження впливу украӥнського визвольного руху у Західній Україні 1940-1950-х рр. на освітнє середовище краю.

Ключові слова: загальноосвітня школа; західні області Украӥни; педагогічні кадри; сталінський режим; повсякденне життя; історіографія.

Jim. 40.

Maria Yarushak, Ph.D.(Pedagogy), Associate Professor of the General Pedagogy and Preschool Education Department, Drohobych Ivan Franko State Pedagogical University

Oleksandra Sviontyk, Ph.D.(Pedagogy), Associate Professor of the General Pedagogy and Preschool Education Department, Drohobych Ivan Franko State Pedagogical University

Mykola Haliv, Doctor of Sciences (Pedagogy), Associate Professor of the History of Ukraine Department, Drohobych Ivan Franko State Pedagogical University

\section{THE SECONDARY EDUCATION OF THE UKRAINE'S WESTERN REGIONS (1944 -} 1953) IN THE EVERYDAY LIFE'S HISTORY DIMENSIONS (historiographical aspect)

Modern Ukrainian historiography of the history of secondary schools everyday life in the western regions of Ukraine in the first postwar years (1944-1953) is analyzed in this article. The study revealed that modern Ukrainian historiography of schools everyday life in the western regions of Ukraine in the first postwar years includes several dozen scientific papers. The authors proposed the division of these works into three groups: 1) works on the history of schooling in the western regions of Ukraine in 1944-1953 (S. Svorak, S. Herehova, R. Popp, I. Sushyk, N. Mashchenko, V. Starzhets, etc.); 2) studies on the everyday life history of different social environments, which included schoolchildren in the western Ukrainian lands of the outlined period (T. Vronskaya, V. Hulay, N. Krasnozhon, R. Popp, L. Romanets, V. Starka, etc.); 3) research of the influence of the Ukrainian liberation movement in Western Ukraine in the 1940s and 1950s on the educational environment of the region (R. Davydyuk, V. Ilnytsky, O. Ishchuk, R. Popp, M. Haliv, V. Starzhets, etc.).

The analysis of the content of these studies allowed to state the following historiographical "gaps": a) the lack of comparison of school education in Volyn, Drohobych, Zakarpattia, Lviv, Rivne, Stanislav, Ternopil, Chernivtsi regions of the Ukrainian SSR; b) the lack of comparison of educational processes of the first years of the postwar period in Western Ukraine with the educational realities of the Ukrainian SSR as a whole; c) the outline by scientists of the daily life of schoolchildren in this region in the first postwar decade is mostly fragmentary and inconsistent. The authors of this article have stated the absence of research devoted to the problem of everyday life of schoolchildren in the western Ukrainian regions of Ukraine in 1944-1953. The implementation of such research is an urgent task of modern Ukrainian historical and pedagogical science.

Keywords: secondary school; western regions of Ukraine; pedagogical staff; Stalinist regime; everyday life; historiography.

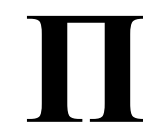

остановка проблеми. Повсякденне життя дітей і молоді західних областей України, які здобували загальну середню освіту у 1944-1953 pp., упродовж останніх десятиліть усе більше привертає увагу українських дослідників. Ця проблематика лежить у контексті одразу кількох напрямів наукових історичних досліджень, насамперед 


\section{ЗАГАЛЬНООСВІТНЕ ШКІЛЬНИЦТВОЗАХІДНИХ ОБЛАСТЕЙ УКРАЇНИ (1944 - 1953) У ВИМІРАХ ІСТОРІЇ ПОВСЯКДЕННЯ (історіографічний аспект)}

історії дитинства, котра набуває популярності серед вітчизняних вчених, а також соціальної історії та історії повсякдення соціальних груп і верств (молоді, інтелігенції, селянства, міського населення тощо). На сьогодні українська історична та історико-педагогічна науки репрезентовані кількома десятками опублікованих досліджень, які потребують належного історіографічного аналізу.

Аналіз останніх досліджень і публікацій. Історіографічний огляд наукових праць, присвячених шкільництву західних областей України у 1944 - 1953 рр., здійснено у дисертаціях Н. Мащенко [15], В. Старжеця [31]. Л. Романець та I. Романюк опублікували спільну працю, присвячену українській історіографії повсякденного життя та соціального статусу вчительства України повоєнного періоду (1944-друга половина 1950-х рр.) [28]. Однак, зважаючи на появу нових наукових студій з історії західноукраїнського шкільництва та повсякденного життя, вважаємо необхідним здійснити аналіз сучасної української історіографії окресленої проблеми.

Мета статті - проаналізувати сучасну українську історіографію повсякденних аспектів загальноосвітнього шкільництва західних областей України перших повоєнних років (1944 - 1953).

Виклад основного матеріалу. Аналізуючи історіографію окресленої проблеми, ми свідомо не беремо до уваги дослідження радянських авторів, які торкалися питання окремих аспектів повсякденного життя школярів (у тому числі на західних землях України 1940-1950-х рр.), проте робили це переважно у ключі демонстрації кількісних показників радянської освіти (розширення мережі загальноосвітніх шкіл, підготовка педагогічних кадрів, збільшення учнівського контингенту) та начебто ефективності форм виховної роботи 3 дітьми (діяльність піонерської та комсомольської організацій, виховні заходи тощо). Серед класичних праць цього типу відзначимо дисертацію Н. Міщенка (1955), монографії О. Філліпова (1957), М. Грищенка (1960), М. Гриценка (1966), В. Струбицького та О. Шпортенко (1969), I. Кошарного (1975), колективні праці “Розвиток народної освіти на Львівщині” (1957) та “Розквіт народної освіти в західних областях України” (1979).

У 1990-х рр. зјявилися перші праці українських учених, у яких доволі об'єктивно, грунтуючись на нових, невідомих раніше джерельних матеріалах, характеризувався процес організації шкільної освіти на західних землях України у перше повоєнне десятиліття. Радянізаційні перетворення у сфері освіти західних областей України 1944 1953 рр. найбільш глибоко проаналізував С. Сворак у серії статей, монографії та докторській дисертації (1997-1999). Дослідник на основі широкого джерельного матеріалу розкрив трансформаційні процеси в освітньому житті Західної України, зокрема і в перші повоєнні роки, чимало уваги присвятив кадровій політиці радянської влади щодо вчительства, проаналізував зміни у змісті освіти та виховання підростаючого покоління, відзначив участь вчителів і учнів шкіл західноукраїнських областей в українському визвольному русі тощо. Особливу увагу вчений зосередив на ідеологічному сегменті освітніх перетворень, запровадженні нових педагогічних концепцій у практику роботи радянської школи в Західній Україні [30]. С. Сворак відзначив такий аспект шкільної освіти у західноукраїнському регіоні, як зростання числа російськомовних шкіл. Водночас він одним 3 перших українських вчених висвітлив окремі аспекти становища польської шкільної молоді у перші повоєнні роки. Дослідник, наводячи численні приклади, зауважив, що польські учні і вчителі протестували проти запровадження в їхніх школах українських стінгазет, викладання української або російської мови. Під тиском батьків учні у польських школах відмовлялися вступати до будьяких дитячих організацій, включаючи Червоний Хрест, не кажучи вже про піонерську чи комсомольську організації. Відзначимо, що, не ставлячи мету розкрити повсякденне життя учнів, дослідник чимало причинився до розкриття тих аспектів освітнього життя на західноукраїнських землях у перші повоєнні роки, які були тісно пов'язанні зі щоденними життєвими практиками шкільної молоді.

Окремі аспекти проблеми досліджувала Неоніла Красножон, аналізуючи вплив суспільнополітичних процесів в Радянській Україні на загальноосвітню школу 1943-1953 pp. (2002) [11]. В одному 3 підрозділів дисертації Степана Демјянчука (2000) проаналізовано становлення системи трудової підготовки учнів у школах радянської України після Другої світової війни, зокрема і на матеріалі західних областей України [7]. Зміст навчально-виховної роботи у загальноосвітніх школах повоєнної України перших повоєнних років аналізувала Людмила Романець (2015) [25], щоправда, дослідниця не наводила даних 3 терен західних областей України. У працях Світлани Герегової (1998, 2004) [3; 4] розкрито формування та функціонування усіх радянської системи освіти в західному регіоні України: загальноосвітньої, фахової та вищої 
ЗАГАЛЬНООСВІТНЕ ШКІЛЬНИЦТВОЗАХІДНИХ ОБЛАСТЕЙ УКРАЇНИ (1944 - 1953) У ВИМІРАХ ІСТОРІЇ ПОВСЯКДЕННЯ (історіографічний аспект)

школи. Дослідниця навела статистичну інформацію про чисельність шкіл, зростання кількості вчителів, відзначила ідеологічний вплив загальноосвітньої школи на учнівську молодь. Володимир Старжець (2017) [32] описав відновлення радянської системи шкільної освіти в західному регіоні України впродовж 1944-1953 pp., зокрема згадав про участь школярів у відбудові шкіл та виготовленні шкільного обладнання у школах Дрогобиччини та Волині.

Деякі аспекти повсякдення молоді у школах трудових резервів України (1943-1950 рр.) розкрив Віталій Король (2017) [9]. Він, зокрема, опрацював архіви Львівської та Рівненської областей, а відтак окреслив стан мережі, кількість учнів та зміст освітнього процесу у зазначених школах західних областей України. Дослідник, зокрема, відзначає насильницькі способи залучення підлітків у західних та інших областях України до навчальних закладів трудових резервів: облави, нічні візити додому, озброєне конвоювання, погоні і засідки тощо [9, 94-95].

Значну частину праць українських істориків присвячено дрібнішим локусам (областям, містам) у межах західного регіону України. Ще 1997 р. Світлана Герегова опублікувала статтю, в якій проаналізувала становище шкільництва (чисельність шкіл, вчителів, учнів, матеріальне забезпечення освіти, ідеологічний вплив на навчально-виховний процес) у школах Чернівецької області другої половини 1940-х рр. [5]. Становлення системи освіти на Волині у 40-50-ті pp. ХХ ст. висвітлила Ірина Сушик (2009) [36]. Серед інших праць “регіонального сегменту” слід виділити студії дрогобицької історикині Руслани Попп, присвячені шкільництву Львівської та Дрогобицької області. Так, у статті “Шкільництво Львівщини у перші повоєнні роки” (1998) розкрито формування загальноосвітньої мережі краю, відзначено окремі аспекти політики радянської влади щодо педагогічних кадрів. 3 іншого боку, авторка охарактеризувала окремі моменти повсякденного життя шкільної молоді Львівської області, описала залучення дітей і підлітків до відбудови матеріальної бази шкіл під час так званих “недільників" і “тижнів школи” [23, 162]. Викликають зацікавлення й наведені на основі архівних документів факти негативного ставлення польських школярів до політики радянських властей [23, 165]. У статті “Шкільна освіта в Дрогобицькій області у перші повоєнні роки (1944-1953)" (2011) Р. Попп зосередила увагу й на окремих аспектах повсякденного життя учнів загальноосвітніх шкіл, приділила увагу зникненню польського шкільництва, низькому рівню відвідуваності шкіл учнями, матеріальнотехнічному забезпеченню освітнього процесу на Дрогобиччині. Дослідниця відзначила нестачу шкільних приміщень навіть в обласному центрі, відсутність підручників та інших засобів навчання $[22,156]$. Позитивною стороною праці Р. Попп 3 історії шкільної освіти на Дрогобиччині у перші повоєнні роки є й увага дослідниці до участі шкільної молоді в українському визвольному русі $[19 ; 20 ; 22]$.

Тему девіацій в освітньому процесі на Дрогобиччині окресленого періоду в одній 3 публікацій висвітлив Микола Галів (2015). Дослідник проаналізував та опублікував низку документів Дрогобицького обласного управління МДБ та обкому компартії щодо побиття учнів у школах області (Меденицького, Дублянського, Мостиського, Дрогобицького, Стрийського районів і м. Самбір) [2, 15]. Серію праць з історії шкільництва у перші повоєнні роки на Рівненщині опублікувала Наталія Мащенко [13; 14; 15; 16]. У кандидатській дисертації (2018) дослідниця комплексно висвітлила процес становлення i розвитку шкільної освіти Ровенської області впродовж 1944-1964 рр. Наводячи чималу кількість джерельних матеріалів і виокремлених на їх основі фактів,

Н. Мащенко розкрила формування мережі початкових, семирічних і середніх навчальних закладів, реалізацію закону "Про загальне обов'язкове навчання”, запровадження уніфікованих навчальних планів, програм, підручників, матеріально-технічне та кадрове забезпечення шкіл Ровенської області тощо. Більш детально повсякденне шкільне життя учнів у 1944-1953 рр. Н. Мащенко описала у розділі про зміст і форми навчально-методичної та виховної роботи у школах Ровенської області. Історикиня слушно відзначає, що часто зміст навчальних програм та їх реалізацію було спрямовано таким чином, що фальсифікували саму українську історію, нівелювали національні традиції українського народу, нехтували здобутками українських учених у вивченні природничих i гуманітарних дисциплін $[15,145]$. Розповідає авторка і про виховну роботу в школах Ровенської області, у цьому контексті підкреслює насильницький характер залучення учнів до піонерської організації. Згідно з їі дослідженням, непоодинокими в області були випадки, коли 3 метою затягування дітей до шкільної піонерської організації їх зачиняли в класах після уроків i тримали без їжі до вечора, відбирали шкільні підручники, ставили незадовільні оцінки чи навіть били $[15,164]$. 


\section{ЗАГАЛЬНООСВІТНЕ ШКІЛЬНИЦТВОЗАХІДНИХ ОБЛАСТЕЙ УКРАЇНИ (1944 - 1953) У ВИМІРАХ ІСТОРІЇ ПОВСЯКДЕННЯ (історіографічний аспекТ)}

Окремі аспекти становища шкільництва на Закарпатті у 1944-1953 рр. висвітлено у працях Лариси Капітан (2013) [8], Октавії Фізеші (2016) [40] та Василя Міщанина (2019) [17]. Зокрема, у дисертації О. Фізеші розкрито зміст нормативних документів, які регулювали реорганізацію шкільництва краю на радянський взірець, показано мережу шкіл області у 1945-1946 н.р., будівництво шкільних приміщень наприкінці 1940 - початку 1950-х рр., зміни кількісних показників учнівського контингенту (зокрема незадовільне виконання закону про загальне обов'язкове навчання в школах Рахівського, Воловського і Перечинського округів), функціонування угорських та румунських шкіл в краї та ін. [40, 252-266] Історик В. Міщанин окреслив радянізаційні перетворення у сфері освіти Закарпаття 1944 1950 рр., значну увагу приділив становищу місцевих і скерованим зі східних областей учителів, натомість недостатньо висвітлив обставини життя і навчання учнів. Важливо, що автор намагався показати прив'язаність місцевих учителів та учнів до народних і релігійних традицій [17, 226-235].

Оскільки школярі західної України належали до різних соціальних верств і груп (інтелігенція, селяни, робітники, службовці тощо) та двох соціально-топографічних локусів (місто і село), то у працях, присвячених зазначеним дослідницьким објєктам, можна зустріти й певний аналіз умов повсякденного життя дітей шкільного віку. Чимало студій присвячувалося соціальній структурі населення повоєнної України загалом та західноукраїнських областей зокрема. Соціальнополітичні процеси в регіоні проаналізував Василь Ткачук (1998) [38]. У 2002 р. з'явилася стаття Василя Гулая про формування соціальнопрофесійної структури населення Львівської області у перше повоєнне десятиліття [6]. Руслана Попп $(2010,2017)$ розкрила різні аспекти формування соціальної структури населення Дрогобиччини у середині 40 - на початку 50 pp. XX ст., а також висвітлила повсякдення мешканців області за матерілами газети "Радянське слово" (2016) [18]. Особливу увагу українських дослідників викликало становище інтелігенції західних областей України. Тут слід відзначити праці Олександра Рубльова та Юрія Черченка (1997), Віктора Даниленка (2003), Руслани Попп (2000-2012), Тамари Марусик (2002), Олександра Луцького (2009), Романа Шляхтича (2011) та ін.

Однією з найбільш досліджуваних соціальних груп $\epsilon$ вчительство. Повсякденне життя вчительства післявоєнної України досліджували
Наталія Красножон (1999) [10], Людмила Романець (2006, 2009, 2010) [24; 26; 27], Іван Романюк (2015) [29]. У студіях зазначених авторів детально простудіювано підготовку педагогічних кадрів, матеріальне забезпечення, ідеологічно-методичне “підвищення кваліфікації”, позашкільну політико-ідеологічну працю учителів (робота агітаторами, пропагандистами) тощо. Формування вчительських кадрів загальноосвітніх шкіл Волині у 40-50-х pp. ХХ ст. окреслила Ірина Сушик (2009) [37]. Кадрове забезпечення шкіл Рівненщини у другій половині 1940-х - першій половині 1950-х рр. проаналізувала Наталія Мащенко (2015) [12]. Ідеологізацію професійної діяльності вчителів початкових шкіл Закарпаття в означений період розкрила Октавія Фізеші (2019) [39].

Низку праць українських істориків присвячено репресіям проти вчителів західних областей України у перші повоєнні роки. Про репресованих учителів як членів родин учасників українського визвольного руху писала Тамара Вронська (2009). У дослідженнях Руслани Попп (2013) [21] і Миколи Галіва (2013) [1] оприлюднено деякі аспекти радянських репресій щодо західноукраїнської інтелігенції, зокрема і проти вчителів на Дрогобиччині. Окремі праці щодо персоналій репресованих учителів (Федір Вишиваний, Олена Ворик, Варвара Журбенко), побудовані на матеріалах архівно-кримінальних справ.

Серед найбільш досліджуваних українськими ученими соціальних верств є селянство, повсякдення якого у перші повоєнні роки висвітлювалося українськими дослідниками. Серед них назвемо праці Олександра Гаврилюка (1995), Віктора Даниленко (2005), Михайла Сеньківа (2007), Володимира Старки (2019). Останній з названих учених виявив повсякденне життя західноукраїнського села в умовах тоталітарних режимів (1939-1953) [35]. Зокрема урозділі “Культурно-освітне життя західноукраїнського села" розкрив особливості сільського шкільництва, щоправда, недостатню увагу приділив власне післявоєнним рокам. Водночас В. Старка окреслив і дозвілля сільських мешканців, відзначивши запровадження (часто невдале, непослідовне, формальне) в традиційне селянське середовище радянських свят, формування при сільських клубах гуртків художньої самодіяльності, демонстрацію кінофільмів тощо. Звісно, усе це стало складовою частиною повсякденного життя школярів західних областей.

Політику структур українського визвольного руху (ОУН і УПА) щодо освіти дітей і молоді аналізували чимало українських учених. Серед них 
передовсім слід назвати Василя Ухача (1998, 2011). До схеми його зацікавлень входила Він аналізував культурно-освітня діяльність ОУН у перші п'ятнадцять років їі існування, тож післявоєнна доба не увійшла до дослідницького простору автора. Дослідники українського визвольного руху відзначали форми співпраці ОУН і УПА з різними соціальними групами, зокрема вчителями та учнями шкіл. Серед них відзначимо праці Юрія Киричука (2003), Олега Дмитерка (2004), Руслани Давидюк (2006), Романа Генеги (2007), Олександра Іщука (2011), Івана Патриляка (2012), Тамари Галицької-Дідух (2013), Олександри Стасюк (2014), Олександра Жосана (2015), Василя Ільницького (2015-2017), Миколи Галіва (2015), Руслани Попп (2020).

Найбільш послідовно і глибоко ця проблема проаналізована у працях Володимира Старжеця (2016-2019) [31-34]. У дисертації він охарактеризував політику ОУН щодо школярів, навів чимало документів цієї організації (постанови зборів, інструкції, брошури, листівки), в яких декларувалися її цілі щодо освіти. Згідно 3 дослідженням В. Старжеця, у перші післявоєнні роки (1944-1946 рр.) українське підпілля намагалося безпосередньо впливати на навчально-виховний процес у школах. У "Методичних вказівках для виховання шкільної дітвори" виховникам рекомендувалося відвідувати шкільні заняття, проводити гутірки, лекції, виступи, на яких переконувати: “Вчитися треба, бо Україна потребує розумних дітей. Вам треба дуже багато вчитися і знати" [31, 83-84]. Найбільш поширеним засобом впливу на учнівську молодь, на думку історика, залишалися листівки, зважаючи на нескладний спосіб їх виготовлення та можливість масового поширення [34]. Акцентуючи увагу на ролі вчителя у вихованні молоді, керівники підпілля розробили й інструкції для педагогів, у яких пояснювали, на яких засадах треба навчати дітей, зауважуючи на важливості протидії сталінській пропаганді. 3 вчителями, що прибували зі східних областей України, підпільники обов'язково проводили бесіди, вимагаючи зосереджуватися винятково на вивченні тієї чи іншої дисципліни, а не займатися ідеологічною пропагандою [31, 87-88]. Значну увагу В. Старжець зосередив на діяльності підпільних організацій школярів, навівши чимало фактів, які стосувалися Рівненської, Дрогобицької, Станіславської, Волинської, Львівської, Тернопільської областей [33].

Висновки. Підсумовуючи відзначимо, що сучасна українська історіографія повсякденного життя загальноосвітніх шкіл західних областей
України перших післявоєнних років налічує декілька десятків наукових праць, які умовно можна поділити на три групи: 1) праці з історії шкільництва західних областей України у 1944 1953 рр.; 2) студії з історії повсякденного життя різних соціальних середовищ, до яких належали школярі на західноукраїнських землях окресленого періоду; 3) дослідження впливу українського визвольного руху у Західній Україні 1940-1950-х рр. на освітнє середовище краю. Аналіз змісту зазначених досліджень дав змогу констатувати такі історіографічні “лакуни”: а) відсутність порівняння шкільної освіти у Волинській, Дрогобицькій, Закарпатській, Львівській, Ровенській, Станіславській, Тернопільській, Чернівецькій областях УРСР; б) відсутність порівняння освітніх процесів перших років післявоєнної доби у Західній Україні з освітніми реаліями УРСР загалом; в) окреслення вченими повсякденного життя школярів зазначеного регіону у перше повоєнне десятиліття має здебільшого фрагментарний і непослідовний характер. Відтак саме у цих, без сумніву перспективних, напрямах науковцям слід працювати.

\section{ЛІТЕРАТУРА}

1. Галів М. Репресії проти службовців та інтелігенції Дрогобицької області у 1946 р.: історично-статистичний нарис. Український націоналізм: історія та ідеї. Науковий збірник. Рожнятів, 2013. Вип. 2. С. 96-104.

2. Галів М. Радянська педагогіка в дії: документи управління МДБ та обкому компартії Дрогобиччини щодо побиття учнів у школах області. Актуальні питання гуманітарних наук. 2015. Вип. 13. С. 13-20.

3. Герегова С. В. До питання впровадження радянської системи освіти в західних областях України в другій половині 40-х - першій половині 50-х років. Питання історіi України. Збірник наукових статей. Чернівці. 1998. Т. 2. С. 133 145.

4. Герегова С. В. Освіта в західноукраїнському регіоні (друга половина 40-х - перша половина 50X pp. XX ст.): автореф. дис. ... канд. іст. наук: 07.00.01. Чернівці. 2004. 22 с.

5. Герегова С. Розвиток народної освіти в Чернівецькій області у другій половинні 40-х років XX ст. Питання історії Украӥни: збірник наукових статей. Чернівці, 1997. Вип. 1. С. 233 241.

6. Гулай В. Формування соціально-професійної структури населення Львівської області (друга половина 40-х - 50-ті роки XX ст.). Наукові 
зочити історичного факультету Львівського національного університету імені Івана Франка. Збірник наукових праџь, 2002. Вип. 4. С. 384-389.

7. Дем'янчук С. П. Трудова підготовка учнів загальноосвітніх шкіл України (1945 - 1991 рр.): автореф. дис. ... канд. пед. наук: 13.00.01. ІваноФранківськ, 2000. 16 с.

8. Капітан Л. І. Етнокультурний розвиток Закарпаття у контексті радянізації краю, 1944 1964 рр. Київ, 2003. 583 с.

9. Король В. Навчальні заклади системи трудових резервів у період відбудови економіки України (1943 - 1950 рр.): дис. ... канд. істор. наук: 07.00.01. Харків-Запоріжжя, 2017. 234 с.

10. Красножон Н. Г. До питань відновлення вчительських кадрів загальноосвітньої школи України (1944-1953). Наукові записки з української історії. Переяслав-Хмельницький. 1999. Вип. XII. С. 345-357.

11. Красножон Н. Г. Загальноосвітня школа України в контексті суспільно-політичного життя (1943-1953 рр.): дис. ... канд. іст. наук: 07.00.01. Київ, 2002. 210 с.

12. Мащенко Н. Кадрове забезпечення шкіл Рівненщини (друга половина 1940-х-перша половина 1950-х років). Науковий вісник Східноєвропейського начіонального університету ім. Лесі Украӥнки. Серія: історичні науки. Луцьк, 2015. Вип. 7 (308). С. 63-67.

13. Мащенко Н. Матеріальне забезпечення шкіл Ровенської області в перше повоєнне десятиліття. Історичні студї Східноєвропейського національного університету імені Лесі Украӥнки. 2015. Вип. 13 - 14. С. 70-76.

14. Мащенко Н. Шкільна освіта на Ровенщині в перші повоєнні роки. Історичні студіі Східноєвропейського начіонального університету імені Лесі Украӥнки. 2014. Вип. 11-12. С. 91-96.

15. Мащенко Н. Шкільна освіта у Ровенській області в 1944-1964 рр.: дис. ... канд. іст. наук: 07.00.01. Луцьк, 2018. 264 с.

16. Мащенко Н. Школи для молоді на Ровенщині в повоєнний час. Актуальні проблеми вітчизняної та всесвітньої історії. Рівне, 2015. Вип. 26. С. 238-240.

17. Міщанин В.В. Радянізація Закарпаття 1944-1950 рр.: дис. ... докт. істор. наук: 07.00.01. Ужгород, 2019. 606 с.

18. Попп Р. Газета "Радянське слово" як джерело вивчення повсякдення населення Дрогобиччини (за матеріалами 1950 року). Дрогобицький краєзнавчий збірник, 2016. Вип. XIX-XX. C. 473-481.

19. Попп Р. Культурно-освітнє життя Дрогобича у повоєнні роки (1944-1953). Україна: культурна спадщина, нащіональна свідомість, державність. 2008. Вип. 17. С. 442-449.

20. Попп Р. Освіта в Дрогобичі у повоєнний період (1944-1953). Дрогобицький краєзнавчий збірник. 2011. Вип. XIV-XV. С. 400-408.

21. Попп Р. Репресії сталінського тоталітарного режиму проти західноукраїнської інтелігенції (1944 - 1953 рр.). Украӥнський націоналізм: історія ma ідеї. Науковий збірник. Рожнятів, 2013. Вип. 2. C. 128-139.

22. Попп Р. Шкільна освіта в Дрогобицькій області у перші повоєнні роки (1944-1953). Проблеми гуманітарних наук. 2011. Випуск 28. Історія. С. 153-164.

23. Попп Р. Шкільництво Львівщини у перші повоєнні роки. Проблеми гуманітарних наук. 1998. Вип. 1. С. 161-169.

24. Романець Л. М. Вчителі загальноосвітніх шкіл УРСР післявоєнного періоду (1945 - друга половина 1950-х років): соціальний статус та повсякденне життя: дис. ... канд. іст. наук: 07.00.01. Черкаси, 2010. 246 с.

25. Романець Л. М. Організація та зміст навчально-виховної роботи в загальноосвітніх школах повоєнної України (1944-середина 1950-х рр.). Освіта, наука $і$ культура на Поділлі. Камјянець-Подільський. 2015. Том 22. С. 118-125.

26. Романець Л. М. Соціальний захист учительства України в другій половині 40-х-50-х рр. XX століття. Наукові записки Вінницького державного педагогічного університету ім. М. Коиюбинського. Серія: Історія. 2009. Вип. 15. С. 133-136.

27. Романець Л. М. Соціально-побутові умови освітян Вінниччини в 1944-1958 рр. Наукові записки Віннииького державного педагогічного університету ім. М. Коцюбинського. Серія: Історія. 2006. Вип. 11. С. 258-261.

28. Романець Л. М., Романюк I. М. Українська історіографія повсякденного життя та соціального статусу вчительства України повоєнного періоду (1944 - друга половина 1950-х років). Література та культура Полісся. Серія: Історичні науки. 2016. Вип. 85. С. 139-156.

29. Романюк I. М., Романець Л. М. Повсякденне життя та соціальний статус вчительства України повоєнного періоду (1944 - друга половина 1950-х років). Вінниця: ТОВ “Вінницька міська друкарня", 2015. 220 с.

30. Сворак С. Д. Народна освіта у західноукраїнському регіоні: історія та етнополітика (1944-1964рр.). Київ: Правда Ярославичів, 1998. 235 с.

31. Старжець В. І. Боротьба радянської влади 
і українського підпілля за вплив на освітній простір західних областей УРСР у післявоєнний період (1944-1953 рр.): дис. ... канд. іст. наук: 07.00.01. Рівне, 2019. $257 \mathrm{c}$.

32. Старжець В. І. Відновлення радянської системи шкільної освіти в західноукраїнському регіоні після війни (1944-1953 рр.). Гілея: науковий вісник. Київ, 2017. Вип. 117. С. 48-52.

33. Старжець В. І. Опір шкільної молоді радянському тоталітарному режимові у західних областях УРСР (1944-1953 рр.). Актуальні проблеми вітчизняної та всесвітньої історії. Рівне, 2017. Вип. 29. С.70-75.

34. Старжець В. I. Пропагандистська діяльність українського націоналістичного підпілля серед вчительства та шкільної молоді (1944-1953 pp.). Актуальні проблеми вітчизняної та всесвітньої icmopii. Рівне, 2016. Вип. 28. С. 109-120.

35.СтаркаВ.В.Повсякденнежиттязахідноукраїнського села в умовах тоталітарних режимів 1939 - 1953 рр. Дис. ... докт. іст. наук: 07.00.01 - історія України. Переяслав-Хмельницький, 2019.540 с.

36. Сушик I. В. Становлення системи освіти на Волині у 40-50-ті роки ХХ ст. Актуальні проблеми вітчизняної та всесвітньої історії. Рівне, 2009. Вип. 17. С. 92-96.

37. Сушик I. В. Формування вчительських кадрів загальноосвітніх шкіл Волині у 40-50-х рр. ХХ ст. Інтелігенція і влада. 2009. Вип. 15. C. 171-180.

38. Ткачук В.П. Соціально-політичні процеси на західноукраїнських землях в перше повоєнне десятиріччя (1944 - 1954 рр.): дис. ... канд. іст. наук: 07.00.01. Львів, 1998. $141 \mathrm{c.}$

39. Фізеші О. Й. Ідеологізація професійної діяльності вчителів початкових шкіл у полікультурному регіоні (на прикладі Закарпаття повоєнного періоду). Вісник Черкаського університету. Серія: Педагогічні науки, 2019. Вип. 2. С. 3-9.

40. Фізеші О.Й. Початкові школи Закарпаття в системних освітніх трансформаціях другої половини XIX - початку XXI століття: дис. ... докт. пед. наук: 13.00.01. Київ, 2016. 587 с.

\section{REFERENCES}

1. Haliv, M. (2013). Represii proty sluzhbovtsiv ta intelihentsii Drohobytskoi oblasti u 1946 r.: istorychnostatystychnyi narys [Repressions against officials and intellectuals of Drohobych region in 1946: historical and statistical essay]. Ukrainian nationalism: history and ideas. Scientific collection, 2, pp. 96104. [in Ukrainian].

2. Haliv, M. (2015). Radianska pedahohika v dii: dokumenty upravlinnia MDB ta obkomu kompartii
Drohobychchyny shchodo pobyttia uchniv u shkolakh oblasti [Soviet pedagogy in action: documents of the MGB and the regional committee of the Drohobych Communist Party on the beating of students in schools in the region]. Current issues of the humanities, 13, pp. 13-20. [in Ukrainian].

3. Herehova, S. V. (1998). Do pytannia vprovadzhennia radianskoi systemy osvity $\mathrm{v}$ zakhidnykh oblastiakh Ukrainy v druhii polovyni 40$\mathrm{kh}$ - pershii polovyni 50-kh rokiv [On the question of the introduction of the Soviet education system in the western regions of Ukraine in the second half of the 1940s and the first half of the 1950s]. Questions of Ukrainian history. A collection of scientific articles, 2, pp. 133-145. [in Ukrainian].

4. Herehova, S. V.(2004). Osvitav zakhidnoukrainskomu rehioni (druha polovyna 40-kh - persha polovyna 50-kh rr. XX st.) [Education in the western Ukrainian region (second half of the $40 \mathrm{~s}$ - first half of the $50 \mathrm{~s}$ of the XX century)]. Extended abstract of candidate's thesis. Chernivtsi, $22 \mathrm{p}$. [in Ukrainian].

5. Herehova, S. (1997). Rozvytok narodnoi osvity v Chernivetskii oblasti u druhii polovynni 40-kh rokiv XX st. [The development of public education in the Chernivtsi region in the second half of the 40 s of the twentieth century]. Questions of Ukrainian history. A collection of scientific articles, 1, pp. 233-241. [in Ukrainian].

6. Hulai, V. (2002). Formuvannia sotsialnoprofesiinoi struktury naselennia Lvivskoi oblasti (druha polovyna 40-kh - 50-ti roky XX st.) [Formation of the socio-professional structure of the population of Lviv region (second half of the $40 \mathrm{~s}-50$ s of the XX century)]. Scientific notebooks of the historical faculty of Ivan Franko National University of Lviv. A collection of scientific works, 4 , pp. 384 389. [in Ukrainian].

7. Demianchuk, S. P. (2000). Trudova pidhotovka uchniv zahalnoosvitnikh shkil Ukrainy (1945 - 1991 rr.) [Labor training of students of secondary schools of Ukraine (1945 - 1991)]. Extended abstract of candidate's thesis. Ivano-Frankivsk. 16 p. [in Ukrainian].

8. Kapitan, L. I. (2003). Etnokulturnyi rozvytok Zakarpattia u konteksti radianizatsii kraiu, 1944-1964 rr. [Ethnocultural development of Transcarpathia in the context of Sovietization of the region, 1944 - 1964]. Kyiv, 583 p. [in Ukrainian].

9. Korol, V. (2017). Navchalni zaklady systemy trudovykh rezerviv u period vidbudovy ekonomiky Ukrainy (1943 - 1950 rr.) [Educational institutions of the system of labor reserves in the period of reconstruction of the economy of Ukraine (1943 1950)]. Candidate's thesis. Kharkiv-Zaporizhzhia. 234 p. [in Ukrainian]. 
10. Krasnozhon, N. H. (1999). Do pytan vidnovlennia vchytelskykh kadriv zahalnoosvitnoi shkoly Ukrainy (1944-1953) [On the issues of restoration of teaching staff of the secondary school of Ukraine (1944-1953)]. Scientific notes on Ukrainian history, XII, pp. 345-357. [in Ukrainian].

11. Krasnozhon, N. H. (2002). Zahalnoosvitnia shkola Ukrainy v konteksti suspilno-politychnoho zhyttia (1943-1953 rr.) [Secondary school of Ukraine in the context of socio-political life (1943-1953)]. Candidate's thesis. Kyiv, 210 p. [in Ukrainian].

12. Mashchenko, N. (2015). Kadrove zabezpechennia shkil Rivnenshchyny (druha polovyna 1940-kh - persha polovyna 1950-kh rokiv) [Staffing of schools in Rivne region (second half of the 1940s - first half of the 1950s)]. Scientific Bulletin of the Eastern European National University. Lesya Ukrayinka. Series: historical sciences, 7 (308), pp. 63-67. [in Ukrainian].

13. Mashchenko, N. (2015). Materialne zabezpechennia shkil Rovenskoi oblasti v pershe povoienne desiatylittia [Material support of schools of Rivne region in the first postwar decade]. Historical Studies of Lesya Ukrayinka East European National University, 13-14, pp. 70-76. [in Ukrainian].

14. Mashchenko, N. (2014). Shkilna osvita na Rovenshchyni v pershi povoienni roky [School education in Rivne region in the first postwar years]. Historical Studies of Lesya Ukrayinka East European National University, 11-12, pp. 91-96. [in Ukrainian].

15. Mashchenko, N. (2018). Shkilna osvita u Rovenskii oblasti v 1944-1964 rr. [School education in the Rivne region in 1944-1964]. Candidate's thesis. Lutsk, 264 p. [in Ukrainian].

16. Mashchenko, N. (2015). Shkoly dlia molodi na Rovenshchyni v povoiennyi chas [Schools for young people in Rivne region in the postwar period]. Current problems of national and world history, 26, pp. 238-240. [in Ukrainian].

17. Mishchanyn, V. V. (2019). Radianizatsiia Zakarpattia 1944-1950 rr. [Sovietization of Transcarpathia 1944-1950]. Doctor's thesis. 606 p. [in Ukrainian].

18. Popp, R. (2016). Hazeta "Radianske slovo" yak dzherelo vyvchennia povsiakdennia naselennia Drohobychchyny (za materialamy 1950 roku) [The newspaper "Soviet word" ("Radianske slovo") as a source of studying the everyday life of the population of Drohobych (based on materials from 1950)]. Drohobych local lore collection, XIX-XX, pp. 473481. [in Ukrainian].

19. Popp, R. (2008). Kulturno-osvitnie zhyttia Drohobycha u povoienni roky (1944-1953) [Cultural and educational life of Drohobych in the postwar years (1944-1953)]. Ukraine: cultural heritage, national consciousness, statehood,17, pp. 442-449. [in Ukrainian].

20. Popp, R. (2011). Osvita v Drohobychi u povoiennyi period (1944-1953) [Education in Drohobych in the postwar period (1944-1953)]. Drohobych local lore collection, XIV-XV, pp. 400408. [in Ukrainian].

21. Popp, R. (2013). Represii stalinskoho totalitarnoho rezhymu proty zakhidnoukrainskoi intelihentsii (1944 - 1953 rr.) [Repressions of the Stalinist totalitarian regime against the Western Ukrainian intelligentsia (1944 - 1953)]. Ukrainian nationalism: history and ideas, 2, pp. 128-139. [in Ukrainian].

22. Popp, R. (2011). Shkilna osvita v Drohobytskii oblasti u pershi povoienni roky (1944-1953) [School education in the Drohobych region in the first postwar years (1944-1953)]. Problems of the humanities 28 (Istoriia), pp. 153-164. [in Ukrainian].

23. Popp, R. (1998). Shkilnytstvo Lvivshchyny u pershi povoienni roky [Schooling in Lviv region in the first postwar years]. Problems of the humanities, 1, pp. 161-169. [in Ukrainian].

24. Romanets, L. M. (2010). Vchyteli zahalnoosvitnikh shkil URSR pisliavoiennoho periodu (1945 - druha polovyna $1950-\mathrm{kh}$ rokiv): sotsialnyi status ta povsiakdenne zhyttia [Teachers of secondary schools of the USSR in the postwar period (1945 - second half of the 1950s): social status and everyday life]. Candidate's thesis. Cherkasy, 246 p. [in Ukrainian].

25. Romanets, L. M. (2015). Orhanizatsiia ta zmist navchalno-vykhovnoi roboty $\mathrm{v}$ zahalnoosvitnikh shkolakh povoiennoi Ukrainy (1944 - seredyna 1950$\mathrm{kh}$ rr.) [Organization and content of educational work in secondary schools of postwar Ukraine (1944 mid-1950s)]. Education, science and culture in Podolya, 22, pp. 118-125. [in Ukrainian].

26. Romanets, L. M. (2009). Sotsialnyi zakhyst uchytelstva Ukrainy v druhii polovyni $40-\mathrm{kh}-50$-kh rr. XX stolittia [Social protection of Ukrainian teachers in the second half of the 1940s and 1950s]. Scientific notes of Vinnytsya Mukhaylo Kotsyubynsky State Pedagogical University. Series: History, 15, pp. 133-136. [in Ukrainian].

27. Romanets, L. M. (2006). Sotsialno-pobutovi umovy osvitian Vinnychchyny v 1944-1958 rr. [Social and living conditions of educators of Vinnytsia region in 1944-1958]. Scientific notes of Vinnytsya Mukhaylo Kotsyubynsky State Pedagogical University. Series: History, 11, pp. 258-261. [in Ukrainian].

28. Romanets, L. M., Romaniuk, I. M. (2016). Ukrainska istoriohrafiia povsiakdennoho zhyttia ta 
sotsialnoho statusu vchytelstva Ukrainy povoiennoho periodu (1944 - druha polovyna 1950-kh rokiv) [Ukrainian historiography of everyday life and social status of Ukrainian teachers in the postwar period (1944 - second half of the 1950s)]. Literature and culture of Polissya. Series: Historical Sciences, 85, pp. 139-156. [in Ukrainian].

29. Romaniuk, I. M., Romanets, L. M. (2015). Povsiakdenne zhyttia ta sotsialnyi status vchytelstva Ukrainy povoiennoho periodu (1944 - druha polovyna 1950-kh rokiv) [Everyday life and social status of Ukrainian teachers in the postwar period (1944 second half of the 1950s)]. Vinnytsia, 220 p. [in Ukrainian].

30. Svorak, S. D. (1998). Narodna osvita u zakhidnoukrainskomu rehioni: istoriia ta etnopolityka (1944-1964 rr.) [Public education in the western Ukrainian region: history and ethnopolitics (19441964)]. Kyiv, 235 p. [in Ukrainian].

31. Starzhets, V. I. (2019). Borotba radianskoi vlady i ukrainskoho pidpillia za vplyv na osvitnii prostir zakhidnykh oblastei URSR u pisliavoiennyi period (1944-1953 rr.) [The struggle of the Soviet government and the Ukrainian underground for the impact on the educational space of the western regions of the USSR in the postwar period (1944-1953)]. Candidate's thesis. Rivne, 257 p. [in Ukrainian].

32. Starzhets, V. I. (2017). Vidnovlennia radianskoi systemy shkilnoi osvity v zakhidnoukrainskomu rehioni pislia viiny (1944-1953 rr.) [Restoration of the Soviet school education system in the western Ukrainian region after the war (1944-1953)]. Hileya: scientific bulletin, 117, pp. 48-52. [in Ukrainian].

33. Starzhets, V. I. (2017). Opir shkilnoi molodi radianskomu totalitarnomu rezhymovi u zakhidnykh oblastiakh URSR (1944-1953 rr.) [Resistance of schoolchildren to the Soviet totalitarian regime in the western regions of the USSR (1944-1953)]. Current problems of national and world history, 29, pp. 70-75. [in Ukrainian].

34. Starzhets, V. I. (2016). Propahandystska diialnist ukrainskoho natsionalistychnoho pidpillia sered vchytelstva ta shkilnoi molodi (1944-1953 rr.)
[Propaganda activities of the Ukrainian nationalist underground among teachers and schoolchildren (1944-1953)]. Current problems of national and world history, 28, pp. 109-120. [in Ukrainian].

35. Starka, V.V. (2019). Povsiakdenne zhyttia zakhidnoukrainskoho sela v umovakh totalitarnykh rezhymiv 1939-1953 rr. [Everyday life of the western Ukrainian village in the conditions of totalitarian regimes 1939 - 1953]. Doctor's thesis. PereiaslavKhmelnytskyi, 540 p. [in Ukrainian].

36. Sushyk, I. V. (2009). Stanovlennia systemy osvity na Volyni u 40-50-ti roky XX st. [Formation of the education system in Volyn in the 40-50s of the $\mathrm{XX}$ century]. Current problems of national and world history, 17, pp. 92-96. [in Ukrainian].

37. Sushyk, I. V. (2009). Formuvannia vchytelskykh kadriv zahalnoosvitnikh shkil Volyni u 40-50-kh rr. XX st. [Formation of teachers of secondary schools in Volyn in the 40-50's of the twentieth century]. Intelligentsia and power, 15, pp. 171-180. [in Ukrainian].

38. Tkachuk, V. P. (1998). Sotsialno-politychni protsesy na zakhidnoukrainskykh zemliakh v pershe povoienne desiatyrichchia (1944-1954 rr.) [Sociopolitical processes in the western Ukrainian lands in the first postwar decade (1944 - 1954)]. Candidate's thesis. Lviv, 141 p. [in Ukrainian].

39. Fizeshi, O. Y. (2019). Ideolohizatsiia profesiinoi diialnosti vchyteliv pochatkovykh shkil u polikulturnomu rehioni (na prykladi Zakarpattia povoiennoho periodu) [Ideologization of professional activity of primary school teachers in a multicultural region (on the example of Transcarpathia in the postwar period)]. Bulletin of Cherkasy University. Series: Pedagogical sciences, 2, pp. 3-9. [in Ukrainian].

40.Fizeshi, O. Y. (2016). Pochatkovi shkoly Zakarpattia v systemnykh osvitnikh transformatsiiakh druhoi polovyny XIX - pochatku XXI stolittia [Primary schools of Transcarpathia in systemic educational transformations of the second half of the XIX - the beginning of the XXI century]. Doctor's thesis. Kyiv, 587 p. [in Ukrainian].

Стаття надійшла до редакції 29.01.2021

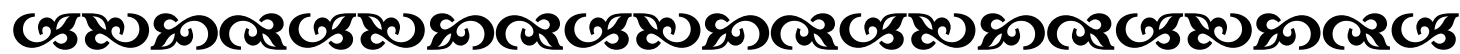

"ТТворіння інтелекту переживають шумну суєту поқолінь $і$ на протязі століть зігрівають світ теплом $і$ світлом”.

\author{
Альберт Ейнштейн \\ один з найвизначніших бізиків ХХ століття
}

“Сильні життєві потрясіння зиіляють від дрібнихстрахів”.

Оноре де Бальзак браниузький романіст $і$ драматург

\title{
G508DC2G5808
}

